\title{
The Old Testament in the First Discourse on Martyrs
}

\author{
Hector Ricardo Francisco \\ Assistant Professor, History Department at the Buenos Aires University; \\ Researcher in the National Scientific and Technical Research Council \\ of Argentina, Buenos Aires, Argentina \\ hectorfrancisco@conicet.gov.ar
}

\begin{abstract}
The aim of this paper is to analyze the use of Biblical Testimonia in the First Discourse of the Holy Martyrs of the Land of Orient (вно 7о6). It will be argued that the main purpose of the author was not only to promote the cult of their relics but also to demonstrate that the persecution was part of God's plan for the Church. As long as Christ, the Apostles and the Prophets were Models for those suffering persecution, the Biblical text was the testimony of the truth of Christian Martyrdom. Moreover, by stressing the continuity between the Heroes of both Testaments and the Martyrs, the author was engaged in a controversy against Marcionism.
\end{abstract}

\section{Keywords}

martyrdom - homily - Marcionism - exegesis

\section{Introduction}

The First Discourse to the Glory and Victory of the Holy Martyrs of the Land of Orient $^{1}$ is a homily composed in Syriac in honour of the Christian martyrs. Although there is no clear indication about their identity, the current scholarly consensus agrees that the martyrs referred to in it were those executed in the

1 BHO 706, henceforth, First discourse. 
persecution under Shapur II circa $340 \mathrm{AD} .^{2}$ In the following pages I will analyze the author's use of biblical Testimonia in the definition of martyrdom and persecution. These Testimonia, I will argue, were the exegetical basis for the promotion of the cult of the martyrs' relics that relied on two principles: first, the oneness of God, creator of an intrinsically Good creation and, second, the unity of Scripture. Concerning this second principle, the author of the First Discourse regarded the biblical text not just as a tool to promote martyrdom. It was also as a key to understand persecution. Moreover, the Testimonia have a side effect: when using biblical references, the author stressed the continuity between Sacred History and the martyrs. At the same time, he engaged in a controversy against those who rejected the inherent unity of both testaments.

The First Discourse is preserved in two manuscripts. The oldest one is Vat. Sir. 161 (fol. 1-18v.) dated in the ninth century. This manuscript had belonged to the Miaphysite Monastery of Deir Al Suriani in Egypt and was brought to Rome by the Maronite scholar J. S. Assemani. The second manuscript is Or. Oct. ${ }_{125} 6$ (pp. 1-151) belonging to the Staatsbibliothek in Berlin. ${ }^{3}$ This manuscript was copied in 1869 from an older one (Ms. $\mathrm{n}^{\circ} 96$ of the Library of the Chaldean Archdiocese of Diyarbakir) dated by Addai Scher between the eleventh and twelfth centuries. ${ }^{4}$ The entire text of the First Discourse was published by Paul Bedjan in the second volume of his Acta Martyrum et Sanctorum based on both known manuscripts. ${ }^{5}$ Despite its potential interest for scholars, the First Discourse was never fully translated into a modern language.

2 On the persecution of Shapur II see: G. Wiessner, Zur Märtyrer-überlieferung aus der Christenverfolgung Schapurs II, Göttingen, 1967; J. P. Asmussen, "Christians in Iran," in: The Cambridge History of Iran. The Seleucid, Parthian and Sasanid Periods, 3.2, ed. E. Yarshater, Cambridge, pp. 933-940; K. Smith, The Martyrdom and History of Blessed Simeon Bar Șabba'e, Piscataway, 2014; idem, Constantine and the Captive Christians of Persia. Martyrdom and Religious Identity in Late Antiquity, Oakland, 2016.

3 J. Assflag, Verzeichnis der Orientalischen Handschriften im Deutschland, V, Syrische Handschriften. Wiesbaden, 1963, pp. 53-59.

4 A. Scher, "Notice sur les manuscrits syriaques et arabes conservés à l'archevêché chaldéen de Diarbékir," Journal Asiatique, 10 (1907), p. 400; W. Macomber, "New finds of Syriac Manuscripts in the Middle East," ZDMG, suppl. I.2 (1969), p. 480.

5 Acta Martyrum et Sanctorum Syriace II, ed. P. Bedjan, París-Leipzig, 1891, pp. 57-122. According to $\mathrm{BHO} 707-708$, in the middle of the fifth century, Abraham the confessor translated the First Discourse into Armenian. See L. Alishan, "Tuununıphı umnnıg unpnju

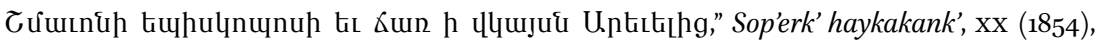

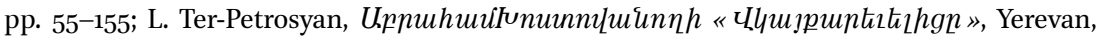
1976. Unfortunately, this last work is not available to us. For further information see M. van Esbroeck, "Abraham le Confesseur (Ve s.) traducteur des Passions des martyrs perses. A propos d'un livre récent," Analecta Bollandiana, 95 (1977), pp. 169-179. 
There is no direct information about its author, date or place of composition. We can only speculate from the hints provided throughout the text. In both manuscripts the first folia are lost, and it is impossible to verify whether the name of the author was provided in the heading. At the ending section of the Homily, the Vatican manuscript (fol. 18v.) simply reads as follows "Ends the discourse which is recited for the glory and praise of all the martyrs that are in the Land of the Orient". In the same way, the Berlin manuscript reads "Ends the first discourse on the Glory and praise of the Holy Martyrs of the Land of the Orient". In spite of this lack of information, the First Discourse has been frequently associated with some of the Acts belonging to the cycle of martyrs' stories under Shapur II, especially with Simeon bar Șabba'ē and his companions. ${ }^{6}$ All of them have common features in contents and style, but it would require further analysis to determine if they were written by the same hand. Notwithstanding, there is little doubt that they belong to the same cultural context.

Those compositions are traditionally associated with two often mistaken known Syriac Christian writers. The first one is the fifth century Bishop of the Roman city of Maypherqaț/Martyropolis and ambassador of the Roman Emperor Theodosius II to the Court of the Šāhānšāh Yazdegerd I, called Marūthā (d. Circa 420). The second candidate is his seventh century namesake Miaphysite Bishop of Takrit $\left(5^{6} 5^{-649)}\right)$. It is quite clear that both attributions are highly improbable. The Catalogus of Stephano Evodio and Joseph Simon Assemani credited the Homily to Marūthā of Takrīt. ${ }^{7}$ However, both the rhetorical style and the contents of the Homily exclude this attribution. If the Homily was actually a work of the Bishop of Takrit, we may expect some kind of polemical statement against Nestorians. However, there is no mention throughout the text about the Christological controversies, and the Christology of the First Discourse seems archaic, closer to the theology of fourth century's Syriac theologians, as Ephrem of Nisibis and Aphrahat the Persian Sage, than to the hellenized theology of seventh century miaphysitism.

6 See вно 1117-1119 and other related Acts. G. Wiessner, Zur Märtyrer-überlieferung aus der Christenverfolgung Schapurs II, pp. 8-39. The introduction to the Martyrdom of Simeon Bar Șabba`e is described in some manuscripts as "The second Discourse" suggesting a continuity with the First Discourse (Cf. Ms. Vat. Sir. 161, fol. 2or, instead Ms. Vat. Sir. 16o, fol. 8ov).

7 S. E. Assemani \& J. S. Assemani, Bibliotheca Apostolica Vaticana codicum manuscriptorum catalogus, Roma, 1759, pp. 324-325. Annunziata Di Rienzo reproduced Assemani's information: $C f$. A. Di Rienzo, Holiness and Power in Syriac Hagiographic Collections, Diss. Ghent University, 2019, p. 36. $C f$. the information provided by E. Villey in http://syriac.msscatalog .org/6516o. 
On the other hand, Stefano Evodio Assemani, Paul Bedjan, Rubens Duval and Anton Baumstark pointed to Marūthā of Maypherqat as the author of a large volume of Martyr stories in which the First discourse may be included as a general introduction..$^{8}$ All these authors rely on the authority of the thirteenth century polymath Abdīšō bar Brikā of Șobā, who, in his catalogue of Syriac writers, stated: "Marūthā, Bishop of Maypherqaț and skilful physician. He com-

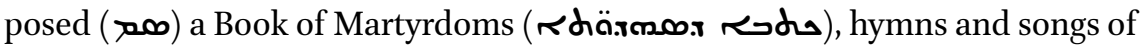
the martyrs". ${ }^{9}$ The eleventh century Arab-Christian Historian 'Amr ibn Mattā pointed in the same direction, although he provided slightly different information: "And Marūthā recollected the relics from the martyrs which were martyred in Orient and he copied every book he found and took them with him".10

From the fragments quoted above two questions arise. First, it is not obvious if Marūthā was an original author, a compiler, or a copyist of the works mentioned by both Abdīšō' and 'Amr. Second, it is highly improbable that the panegyric in question may have been the original introduction to the compilation. We may rather consider that those works were collections of martyrs' stories without any introductory homily. Thus, although the attribution to Marūthā of Maypherqat seems more likely, we cannot conclude with any degree of certainty that the works mentioned could be associated to the First Discourse.

Paul Peeters ${ }^{11}$ has questioned Marūthā's authorship and Robert Murray has directly argued against it, stressing that the Memrā "represents the persecution is still raging and is written in a very wordy, rhetorical style". ${ }^{2}$ Although it is apparent that the author and his audience experienced persecution, the triumphalist overtone, the insistent distinction between "us" (the believers) and "them" (the martyrs), and the mention of the tragic fate of the persecutors seem to point to some gap in time between the persecution and the composition of the homily. Despite this chronological observation, Murray is right to

8 S. E. Assemani, Acta ss. Martyrum orientalium et occidentalium, Roma, 1748, p. xlvii; Acta Martyrum et Sanctorum Syriace II, ed. P. Bedjan, p. 57, n. 3; R. Duval, La littérature syriaque, Paris, 1907, p. 123; A. Baumstark, Geschichte des Syrischen Literatur mit Ausschluss der Christliche palästinischen Texte, Bonn, 1922, pp. 53-54. For a comprehensive view see: C. Jullien, "Les Actes des martyrs perses: transmettre l'histoire," in: L'hagiographie syriaque, ed. A. Binggelli, Paris, 2012, pp. 131-132.

9 Carmen Ebedjesu Metropolitae Sobae et Armeniae continens catalogum Librorum omnium ecclesiasticorum, ed. J. S. Assemani, Bibliotheca Orientalis Clementino Vaticana, Roma, 1725, pp. 73-74.

10 Maris, Amri et Slibae: De Patriarchis nestorianorum commentaria ex codicibus vaticanis. Pars prior, Maris textus arabicus, ed. H. Gismondi, Roma, 1899, 30-31.

11 P. Peeters, "La date du martyre de S. Siméon archevêque de Séleucie Ctésiphon," Analecta Bollandiana, 56 (1938), p. 121.

12 R. Murray, Symbols of Church and Kingdom, Cambridge, 1975, p. 34. 
include the First discourse in the same group of Syriac writers of the fourth and fifth centuries like Aphrahat the Persian Sage, Ephrem of Nisibis or Isaac of Antioch. As mentioned above, many features of the text (as the archaic Christology, the quotations of the Diatessaron, the exegetical methods and the theological motives and images) point to an author that lived prior to the Christological controversies of the fifth and sixth centuries.

Finally, another potential candidate to the authorship has been proposed, namely the Catholicos Ahay (410-414). ${ }^{13}$ According to The Chronicle of Seert ${ }^{14}$ and 'Amr ibn Mattā, 15 Ahay wrote a (currently lost) "Book on the deeds of the martyrs". However, as in the case of Marūthā, it seems more fitting to conclude that this work was a compilation of stories with no direct relation with the First Discourse.

To conclude, we may consider the First Discourse as written by an anonymous author. Although we do not know his name, we can make a few assertions about the context in which he lived. The long section dedicated to the "Orient", 16 lamenting the sufferings of the Christians of his Land, clearly indicates that he delivered the speech before an audience residing in the Sasanian Empire. However there is no other hint about the exact place, nor there is any indication about a specific sanctuary or any particular martyr. This lack of local flavour may allow us to conclude that the composition was intended as general praise to the martyrs independently of any explicit individual. The manuscript tradition seems to confirm that the First Discourse was intended as praise for the martyrs of the persecution of the fourth century, but the author avoids providing names. As a result, both the lack of any indication about a specific sanctuary or the names of the martyrs are indicative of the author's intentions. Although homilies on martyrs with a more general subject are not lacking in Late Antique literature, ${ }^{17}$ most of them were "Hagiobiographical literature" that is, dedicated to praising particular individuals through the narration of

13 P. Bruns, "Reliquien und Reliquienverehrung in den syro-persischen Martyrerakten," Romische Quartalschrift fur Christliche Altertumskunde und Kirchengeschichte, 101 (2006), p. 210.

14 Histoire nestorienne (Chronique de Séert). Première partie. (II), ed. Scher, A. \& P. Dib, (PO 5.2), Paris, 1910, p. 325.

15 Maris, Amri et Slibae: De Patriarchis nestorianorum commentaria ex codicibus vaticanis. Pars altera, Amri et Slibae textus arabicus, ed. H. Gismondi, Roma, 1896, Tr.

16 First Discourse, pp. 97-104.

17 For example, Greek and Syriac Fathers composed homilies on martyrs without any specific reference. See: John Chrysostom, The Cult of the Saints: Select Homilies and Letters, trad. W. Mayer \& B. Neil, New, York, 20o6, pp. 217-226; Nachträge zu Ephraem Syrus, ed. E. Beck, (csco 363), Leuven, 1975; Narsai doctoris Syri Homiliae et carmina, Vol. 1, ed. A. Mingana, Mosul, 1905, pp. 228-245, 401-405; P. Krüger, "Traduction et Commentaire de 
their lives and executions. ${ }^{18}$ In these cases the author's intention was to present them as models of Christian behaviour and to promote their cult. On the contrary, the First Discourse was intended as a theological dossier concerning martyrdom and persecution.

Thus, although it is impossible to identify the author of the First discourse, we can conclude that he was a Christian (without any doubt a member of the clergy) living in the Sasanian Empire between the end of the fourth and the middle of the fifth century. Both the author and the audience may have witnessed persecution or, at least, it was still fresh in the collective memory. Although the place and the occasion of the speech are not clearly mentioned, we can speculate that it was delivered in the Great Feast dedicated to the martyrs, perhaps in the Sanctuaries of Ctesiphon or Karkhā d-Ledan. ${ }^{19}$

\section{$2 \quad$ Structure and Contents: The Bible and the Theology of Martyrdom in the First Discourse}

There are at least five distinct sections in the Homily. In the first section (pp. 57-82) the author praised the martyrs developing Christological metaphors common to Syriac tradition. In the second section (pp. 82-97) the author lauded the female martyrs and described their victories over their male persecutors. The third section (pp. 97-104) is dedicated to a Lament for the Land of the Orient. In the fourth section (pp. 104-111) the author assumes the voice of the Church in a Lament for its Bishops and Priests. The fifth and last section (pp. 111-122) is a long chain of biblical Testimonia devised to demonstrate God's favour to his Church in times of tribulation.

This is not the place to make a detailed account of the contents of each section. It suffices to say that the author deployed traditional images and themes to describe martyrs and martyrdom. His intention was to present them as models

L'Homélie de Narsai sur les Martyrs. Contribution à l'étude des Martyrs dans le nestorianisme primitif," Parole de L'Orient, 3.1 (1958), pp. 299-316.

18 J. Leemans, A. Pauline \& D. Boudewijn, Let us Die that We May Live: Greek Homilies on Christian Martyrs from Asia Minor, Palestine and Syria (c. AD 350-AD 450), London, 2003, pp. 22-37.

19 A. J. McLean, East Syrian Daily Offices. London, 1894, p. 274; Traités d'Isaï le docteur et de Hnana d'Adiabéne sur les Martyrs, le Vendredi d'or et les Rogations, ed. A. Scher, (PO 7.1), Paris, 1911, pp. 27-29; F. Cassingena-Trévedy, "Lorganisation du Cycle Annuel," in: Les liturgies syriaques, ed. F. Cassingena-Trévedy \& I. Jurasz, (Études Syriaques 3), Paris, 2006, pp. 13-48; M. Debié, "Hagiographie et liturgie en dialogue: la soghitha du roi et des martyrs persans," in: Mélanges Bernard Flusin, ed. A. Binggeli, \& V. Déroche, ( TM 23), Paris, 2019, pp. 179-96. 
of Christian behaviour and, as a consequence, to promote the cult around their relics. The metaphorical language applied to describe the Christian heroes depended on more or less long lists of biblical Testimonia which functioned as confirmation of the truth of Christian martyrdom. Instead of a full description, I would like to highlight a few general themes developed along the text which are relevant to my point. First, the main concern of the author was to provide a theology of martyrdom based on the typological connection between biblical figures (the prophets, the apostles and, especially, Christ) and the martyrs. In the author's view, the sufferings derived from martyrdom were the way in which mankind was allowed to participate of Christ's passion at the Cross and so attained salvation. The author, quoting Paul's epistles, stressed that Christ opened the path to salvation and in this manner freed humankind from Sin:

He [Christ] suffered first because of them, as the Apostle said: "Jesus the Messiah died for us so that whether we are awake or asleep, we will all live with Him" (1Thes 5: 9-10). And with His death, He was our saviour and with His blood He remitted the sins and with His blood "He was our tranquillity and He made the two into one" (Eph. 2: 14). ${ }^{20}$

In return for the Saviour's passion, the martyrs "repaid blood with blood, and exchanged life with life, animated beings with spiritual things [...] and they gave their few days as a loan so that they will be returned years of generations (Amos 9: 11 )". ${ }^{21}$ The relationship which links the martyrs to Christ is not mere imitation, ${ }^{22}$ but it is also described as the payment of a debt or as a pledge

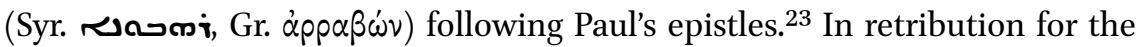
Saviour's sacrifice, the martyrs assumed death in the hope of the recompenses in the next world. As a consequence, the author projected a comparable connection between their bones and the Lord's body. Christian believers - by honouring their relics - could receive their blessings since both are sources of salvation for mankind. ${ }^{24}$

$20 \quad$ First Discourse, p. 65.

21 First Discourse, pp. 65-66.

22 On this topos see: V. Saxer, Bible et Hagiographie. Textes et Thèmes Bibliques Dans Les Actes Des Martyrs Authentiques Des Premiers Siècles, Berna, 1986, pp. 220-231.

23 First Discourse, p. 66, where alludes to Eph 1:14 and 2 Cor 1: 22 y 5:5. Cf. L. Canetti, "Christian Gift and Gift Exchange from Late Antiquity to the Early Middle Ages," in: Gift Giving and the 'Embedded' Economy in the Ancient World, ed. F. Carlá \& M. Gori, Heidelberg, 2014, p. 340 .

24 First Discourse, p. 70. 
The bond that connects the martyrs, the heroes of the Bible and Christ was explained in terms of typological figuration, since the passion of the Lord was viewed as the archetype of martyrdom. By means of the contemplation of the sufferings of the martyrs (which foreshadowed the Lord's Passion), the human eye could gain access to the transcendent Truth of the divinity. This bond between the martyrs and Christ was explained using the metaphor of the shadow and the Body:

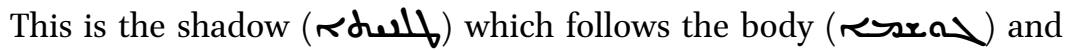
the image (Rdoحx) which accords with the true archetype (ralad rivir). The eye rests in both: in the humanity and the divinity, in the creation and its creator, in the serfdom and the lordship. ${ }^{25}$

Related with this Christological dimension of martyrdom, we can identify in this fragment some common typological methods and ideas of the (Greek and Syriac) exegetical tradition. The relationship between the shadow and the truth is a well-known metaphor used to represent the bond between both Testaments. For instance, in his homily dedicated to commenting 1Cor. 10: $1^{26}$ John Chrysostom explained this connection using as an example the acquaintance between a painting and the actual person represented in it. When he explains the limits of the Old Testament as a cloudy sketch in contrast to the image that is the New Testament, Chrysostom asked his audience to establish the difference between the type ( $\tau \dot{u} \pi \circ \varsigma)$ of truth $(\dot{\alpha} \lambda \dot{\eta} \theta \varepsilon i \alpha)$ and the shadow $(\sigma \kappa i \dot{\alpha})$. Then, he clarified the difference between them appealing to the example of the Emperor and his portrait: "From what you see portrayed you cannot know everything, and yet you are not entirely ignorant". In other words, just as the shadow or the painting can only imperfectly portray the body, the Old Testament is an imperfect image of the truth contained in the New Testament. ${ }^{27}$

Some generations later, Theodoret ${ }^{28}$ commented the Book of the Exodus pointing out that the old things were types ( $\tau \dot{0} \pi \circ \varsigma)$ of the new ones. Thus,

\footnotetext{
25 First Discourse, pp. 70-71.

$26 \quad P G$ LI, col. 247.Cf. M. M. Mitchell, The Heavenly Trumpet: John Chrysostom and the Art of Pauline Interpretation, Tubingen, 200o, p. 54 and G. Frank, "The Image in Tandem: Painting Metaphors and Moral Discourse in Late Antique Christianity," in: The Subjective Eye: Essays in Culture, Religion, and Gender in Honor of Margaret R. Miles, ed. R. Valantasis, D. J. Haynes, J. D. Smith, J. F. Carlson, Eugene, 20o6, p. 39.

27 See: J. Daniélou, From Shadows to reality. Studies in Biblical Typology of the Fathers, London, 196o (1950), p. 19 .

$28 \quad P G$ LXXX, col. 257.
} 
concluded the Bishop of Cyrus, the Law of Moses was the shadow ( $\sigma$ xid) and the Goodness ( $\chi \dot{\alpha}$ pı $)$ of Christ was the body. In a similar way, Ephrem of Nisibis in his Hymns On virginity XIV.7 portrayed the rock of Dan. 2: 34 as a type of Christ. He concluded: "A wonder to see: the symbol (Rir) and its archetype

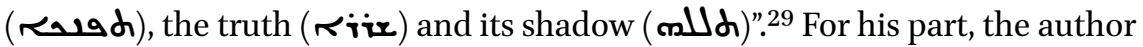
of the First Discourse applies the same typological methods to depict the relation between Christ and the martyrs. As the shadows sketched the body (without fully representing it) the Christian heroes were a representation of the Passion of the Lord. Thus, the believer, fixing his eyes on them, was capable of perceiving the divinity. At this point, the parallel between biblical exegesis and martyrial theology is evident. As the ancient Law is a limited (but necessary) antecedent to the Gospel, the sufferings of the martyrs are described as a way to achieve Christ's passion. This is the key by which the Testimonia on persecution must be decoded.

The Fifth Part: The Old Testament as a Key to Face Persecution

As we mentioned above, the fifth and final section of the First Discourse is a long catena of biblical Testimonia. ${ }^{30}$ The aim of the author was to provide a response to a pressing question: Why did God deliver his Church to persecution? To answer it, the author invoked the prophets and apostles as the source of relief for those who experienced tribulation. ${ }^{31}$ Both the prophets and the

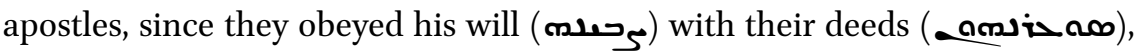
were "the shadow (rduلl) of their Lord". Thus, the author urged his audience to meditate on their words in order to attain their assistance:

Then, let us contemplate them with the secret eye of the soul, and shape them on the internal organs of the breast. Let us collect our mind and fix (the mind) on them. Let us examine them and consider if we find

29 Des heiligen Ephraem des Syrers Hymnen de Virginitate, ed. E. Beck, (csco, 223), Leuven, 1962, p. 49.Cf. R. Murray, Symbols of Church and Kingdom, p. 211; E. Beck, Zur Terminologie von Ephraems Bildtheologie. Regensburg, 1981; Ephraim's Prose Refutations of Mani, Marcion and Bardaisan, ed. C. W. Mitchell, Oxford, 1912, p. 149.

$30 \quad$ R. Murray, "Some Rhetorical Patterns in Early Syriac Literature," in: A Tribute to Arthur Vööbus: Studies in Early Christian Literature and Its Environment, Primarily in the Syrian East, ed. R. H. Fischer, Chicago, 1977, pp. 109-131; M. C. Albl, "And Scripture Cannot Be Broken": The Form and Function of the Early Christian Testimonia Collections, Leiden, 1999.

31 First Discourse, p. 111: "Let us seek the consolation of the prophets for our grief, and let us bring the relief of the apostles for our suffering". 
the punishment for our sins, the consolation for our adversities and the threat of our persecutors. ${ }^{32}$

In the excerpt quoted above the author described the intellectual process by which the believers - reading from the Scriptures and guided by faith - may reach true knowledge. ${ }^{33}$ Unlike the corporal eyes, the "secret eye of the soul" did not rely on visible things but on the shadows (the prophets and the apostles) contained in the types of the Scripture that allowed the mind to ascend unto the true archetype (i.e. Jesus). So, while "the secret eye of the soul" contemplated prophets and apostles as shadows of Christ, the Heart (as the centre of intelligence) made them comprehensible. In this process, prophetic and apostolic traditions were not just presented as ethical models for Christian behaviour. ${ }^{34}$ In addition, their words have a prophetical value, because they did not only speak from a distant past: their words also announced the present tribulations of the Church.

Now, I will turn briefly to the contents of the Catena of Testimonia. Twenty-two out of the twenty-five references were taken from the Old Testament while the last three belonged to the New Testament. Each one of the Testimonia is formed by three (although sometimes there are only two or one) Bible quotations organized on the basis of three topics. The first quotation refers "to our consolation", the second "on the chastisement", and the third "on the persecutors". Each Testimonium is directly related to a biblical figure and designed as a scriptural testimony concerning these three topics. Thus, through the words of each figure, the author was giving an interpretation of the persecution in order to provide relief to his audience, revealing its pedagogic dimension as a chastisement for the sins of the Church and to warn his audience about the fate reserved to the persecutors. In other words, the author devised this list as an instructive to face the persecution which fell upon the Church. ${ }^{35}$ The following table summarizes the quotations:

$32 \quad$ First Discourse, p. 112.

33 See the same process in Ephrem's De Fide, v, 18. Des heiligen Ephraem des Syrers Hymnen de Fide, ed. E. Beck, (csco 155), Leuven, 1955, p. 23; Cf. S. P. Brock, The Luminous Eye: the Spiritual World Vision of Saint Ephrem, Kalamazoo, 1992, pp. 71-79.

34 On Biblical figures as models of martyrdom see B. A. G. M. Dehandschutter, "Example and discipleship: some comments on the biblical background of the early Christian theology of martyrdom," in: The Impact of Scripture in Early Christianity, eds. J. den Boeff \& M. L. van Poll van de Lisdonk, Leiden, 1999, pp. 20-27.

35 One of the unusual features of the Catena is the characterization of the Old Testament figures. They were in fact described as prophets although, strictly speaking, four of them (Moses, Joshua, Job and David) are not part of the prophetic tradition. This mean that these figures did not belong to the canonical prophetic books, although some of them (like Moses or David in Acts 2: 30) were often characterized in Jewish and Christian 


\section{Consolation Chastisement $\quad$ Persecutors}

\section{Old testament (Prophets)}

\begin{tabular}{|c|c|c|c|c|}
\hline 1 & Moses & Deut 32: 43 & Deut 32: 39 & Deut 32: $23^{-25}$ \\
\hline 2 & Joshua & Jos $24: 14,18$ & Jos 24: 19, 20 & Jos 11: 6,20 \\
\hline 3 & Samuel & 1 Sam 12: $23^{-24}$ & 1 Sam 2: 10, 3 & 1 Sam 2: 10 \\
\hline 4 & David & Ps $74: 1$ & Ps 6o: $3,44: 23$ & Ps $69.26-27$ \\
\hline 5 & Elijah & 1 Kgdms 18: 30; 37 & 1 Kgdms 19: 10 & uncertain \\
\hline 6 & Isaiah & Is $35: 3^{-4}$ & Is 3 o: 15 & Is $26: 21$ \\
\hline 7 & Jeremiah & Jer 20: 13 & Jer 12: 7 & Jer 17: $17-18$ \\
\hline 8 & Daniel & Dan 9: 16-18 & Dan 9: 7-12 & Dan 11: 18-19 \\
\hline 9 & Ezekiel & Ez 9: 4 & Ez 24: 21, 25: 4 & Ez 22: 13, 27 \\
\hline 10 & Job & Job 42: $12^{a}$ & Job 16: 6, 19: 2O-21 & Job 9: 1, 12: 6 \\
\hline 11 & Hosea & Os 6: $1-2$ & & Os 9: 7,9 \\
\hline 12 & Joel & Joel 2: 17 & & Joel 2: 20 \\
\hline 13 & Amos & Amos 5: 15, 14 & & Amos 5. 11 \\
\hline 14 & Obadiah & Obad 1: 17,21 & & Obad1: 15,10 \\
\hline 15 & Jonah & Jonah 2: 3, 5 & & Jon. 2: 9 \\
\hline 16 & Micah & Micah 7: 9-10 & & Micah 2: 1-2 \\
\hline 17 & Nahum & $\mathrm{Na} 1.7$ & & Na 1: 2 \\
\hline 18 & Habakkuk & Hab 2: 3 & & Hab 2: $16-17$ \\
\hline 19 & Zephaniah & Zeph 2: 8, 20 & & Zeph 1: 12 \\
\hline 20 & Haggai & $\operatorname{Ag} 2: 4-5$ & & Ag 1: 6 \\
\hline 21 & Zechariah & Zech 8: 7-8 & & Zech 9: 6 \\
\hline 22 & Malachi & Mal 3: 7 & & Mal 1: 4 \\
\hline
\end{tabular}

\section{New Testament (Jesus and Apostles)}

$\begin{array}{llll}1 & \text { Jesus } & \text { Luke 12: 11-12, } & \text { Luke 21: 12-13, } \\ & & \text { Matt. 10: 19, } & \text { Mark 13:9 } \\ & & \text { Mark 13: } 11 & \\ 2 & \text { Peter } & \text { Acts. } 3: 19 & \\ 3 & \text { Paul } & \text { 2 Cor } 4: 8-10 & 2 \text { Thes } 6-9\end{array}$

a In this case the order is inverted. 
The table 1 shows that the method of the author was far from rigid. On the contrary, the tripartite structure was maintained only in the first ten cases, while in the rest it was partially modified, omitting one or two components of the ensemble. Moreover, quotations were rarely verbatim. On the contrary, there was a tendency to paraphrase as well as numerous additions in order to clarify or expand their meanings. Finally, and as we mentioned above, the quotations of the Gospels were taken from the Diatessaron. ${ }^{36}$ Besides this, it is worth noting the unity in the meaning of the catena as a whole, to the extent that it can be characterised as repetitive. It is not my aim to analyze in detail the form and contents of every quotation included in each ensemble. Rather, I want to highlight two consequences derived from this arrangement. First, from the author's point of view, Christians should appeal to the sacred text in order to find the meaning of persecution. This appeal was based on the notion that the tribulations experienced by the Church were an integral part of God's plan. This bond allowed the author to consider in further detail the continuity between the Old and the New Testaments. Following the Testimonia, the author proclaims the unity of both parts of the Scripture while - at the same time - they were the key to define martyrdom. Consequently, the prophets and the apostles were equals to the martyrs since both suffered for the sake of God:

We have examined the Old and the New (Testaments) and we inquired into the prophets and apostles. And we found the consolation of our sufferings and the chastisement ( rharios) for our sins. And we were comforted and our mind received consolation. We have compared them and ourselves, and we made ourselves worthy of them. There is Justice and Goodness, there is punishment and remission, there is retribution and mercy, there is judgment and compassion, there is fear and encouragement, and there is Death and Life. And with their prophecy and their preaching they happen to be our companions (טבت have been chastened ( $\sim$ ridir) like us, and they have been recognized by us as company (حسم) (حه) that has been beaten like us. ${ }^{37}$

The chain of Testimonia viewed as a whole, developed four ideas. The first one is the pedagogic dimension of persecution. The sufferings and tribulations

literatures as "Prophets" Cf. M. Daly-Denton, "David the Psalmist, Inspired Prophet: Jewish Antecedents of a New Testament Datum," Australian Biblical Review, $5^{2}$ (2004), pp. 32-47 and W. Meeks, The Prophet-King:Moses Traditions and the Johannine Christology, Leiden, 2017.

$36 \quad$ R. Murray, Symbols of Church and Kingdom, p. 231.

37 First Discourse, p. 119 . 
experienced by the Christians were the just punishment of God for their sins. Divine punishment also led People to repentance and moved them to submit to God's Will. ${ }^{38}$ The second idea derived from this arrangement is that, in spite of the persecution, God has never forsaken his flock. On the contrary, thanks to God's mercy the tribulations were destined to find an end. The words of prophets and apostles - the author said - reminded the audience that by their sufferings men can attain the forgiveness of their sins and the recompense in the world to come. I have already mentioned that the author defined martyrdom as an investment that is complementary to the promise of a reward reserved to saints. The third idea is that the persecutors were not blameless instruments of God's wrath. On the contrary, they have a moral responsibility concerning persecution, and their impending destruction is the just retribution reserved by God for their evil acts. The fourth and last idea is structured around the sufferings as the driving force which connects past and present. Through the same sufferings, the persecuted Christians became companions (טבتזم) and company (حسم) of prophets and apostles. In this way, the Scripture surpasses its literal connotation to provide a meaning to the experience of present-day persecution.

At first sight, it is tempting to relate the Testimonia of the last section of First Discourse with the ideas developed by Aphrahat in his XxI Exposition, titled On Persecution. ${ }^{39}$ Although both texts show several affinities in themes and references, there are also significant differences between them. Sure enough, both authors were writing on behalf of an audience that had experienced persecution. However, their claims were somewhat different. In his Exposition, the Persian Sage defended the persecuted Christians against the charges of a - may be fictional -Jewish adversary who accused them of ungodliness. According to Aphrahat, his opponent quoted Math. 17: 19 to prove that Christian faith was ineffective because despite their prayers, God allowed their persecution. The Christian writer refuted those charges saying that if the Christians were persecuted, the Jews themselves had been persecuted in the past as well. To sustain this claim, he evoked a list of righteous men persecuted in the Old Testament.

38 This pedagogical dimension of the persecution is indicated by the semantic field of the term rdaris. This well-known noun (derived from de root , זri "to instruct", "to chastise" and that in the Syriac Bible this term often corresponded to the Greek $\pi \alpha$ เ $\delta \varepsilon^{\prime} \alpha$ ) can be translated alternatively as "chastisement", "discipline", "instruction" or "culture". The author developed this same idea some pages before (First Discourse, p. 61), where he explained that the killing of the righteous by means of the impious was part of God's plan to instruct his people.

Aphraatis sapientis Persae Demostrationes, ed. J. Parisot, (PS 1.1), Paris, 1894, cols. 931-99o. 
The archetype of all those righteous was Christ himself. ${ }^{40}$ Briefly, the persecution did not demonstrate the impiety of the Christians. Quite the opposite, in being persecuted the Church was equated to the heroes of Ancient Israel and, by extension, participated in the Passion of Christ. Thus, Aphrahat concluded, the memorial of the persecution suffered by Christ and the righteous of the Old Testament was a source of relief for the Christians.

As I have stated above, some of the themes (even specific biblical references ${ }^{41}$ ) deployed by Aphrahat have parallels in the First Discourse. However, the Persian Sage avoided any explicit recognition of the relation between the Christians' sins and the persecution as a pedagogical device ministered by God, an idea that was paramount to the author of the First Discourse. This difference in emphasis is easily explained if we take into account the insistence of the First discourse in the sins of the Christian community is quite similar to the charges made by Aphrahat's Jewish opponent.

In addition, Aphrahat was writing when persecution was still in progress. His main goal was to maintain the cohesion and allegiance of a community whose position in the social and political order was at stake. On the contrary, the author of the First Discourse, instead of defending the Christians from the attacks directed from the outside, was trying to reinforce the bond between the cult of the martyrs and the Biblical past in a relatively different context. If we are right to date the Homily to the first half of the fifth century ${ }^{42}$ then there was no need to defend the Church from the attacks of outsiders. On the contrary, from its very same contents it becomes apparent that the author considered the Church had experienced a moral decadence due to the period of peace after the persecution. ${ }^{43}$

40 J. Neusner, Aphrahat and Judaism: the Christian-Jewish argument in fourth-century Iran, Leiden, 1971, pp. 133-134.

41 For example, see the coincidences in the references to King Josiah or Judah Maccabee as models of martyrdom. Cf. First Discourse, p. 92, 100-101 and Aphraatis sapientis Persae Demostrationes, col. $988,972$.

42 During the first three decades of the fifth century the Christians in the Sasanian Empire lived in a changing situation with alternative moments of peace (even with explicit royal support) and others of persecution. See. L. Van Rompay, "Impetuous Martyrs? The Situation of the Persian Christians in the last Years of Yazdgard I (419-421)," in: Martyrium in Multidisciplinary Perspective. Memorial Louis Reekmans, ed. M. Lambergis \& P.Van Deun, Leuven, 1995, pp. 363-375; S. McDonough, "A Second Constantine?: The Sasanian King Yazdgard in Christian History and Historiography," Journal of Late Antiquity, 1.1 (2008), pp. 127-140, G. Herman, "The Last Years of Yazdgird I and the Christians," in: Jews, Christians and Zoroastrians: Religious Dynamics in a Sasanian Context, ed. G. Herman, Piscataway, 2014, pp. 67-90.

$43 \quad C f$. the beginning of the Homily where the author confronted the luxury and the moral failures of his contemporaries with the steadfastness and endurance of the Martyrs. 
Notwithstanding, the First Discourse has an undoubtedly polemical goal. Indeed, at the beginning of the homily the author alleged that "someone who did not participate of our suffering" rebuked Christians claiming that the sufferings experienced by the martyrs were not related to God's Will, but to mundane fortuitous events that raised pride and impiety. ${ }^{44}$ These claims were significant not only because they untied the persecution from God's plan. The persecution was, most of all, the result of Christian pride and boldness. The author resorted to the testimony of the prophetic tradition and the Gospel in order to point that God disciplined his people through persecution and tribulation. As would be expected, such an answer was built around a chain of Biblical Testimonia (namely Is. 47: 6, Jer. 15: 7, 1Cor. 11: 32, Lc. 12: 47-48, 2 Mac. 5: 17; 7: 32-33).

It is worth noting that - unlike the case of Aphrahat - the opponent was never fully identified. All the more, the expression "someone who did not par-

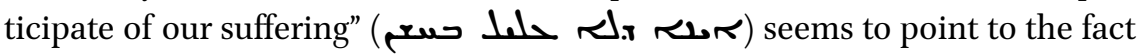
that what divided the author from his adversary was more from a moral than a theological stance. Did this adversary come from outside the Church or was one of its members? This question leads us back to the passage quoted above in order to find the answer. As already mentioned, the Testimonia were the confirmation that God favoured his flock in times of persecution. But it was also the confirmation of the continuity between the Old and New Testaments. The author organized this continuity by posing contrasting concepts that differentiated but, at the same time, equated both parts of the Scripture:

The concepts in the table 2 were presented as alternative forms by which God enters in the covenant with his people. Compared with the revelation of the New, the Old Covenant was viewed as inferior, but it was unquestionably

TABLE 2 Concepts in the scripture (First Discourse, p. 119)

\begin{tabular}{|c|c|}
\hline Old testament & New testament \\
\hline Justice (حمصם) & Goodness or Grace (rdaר \\
\hline Punishment (مdح & Remission (عمحمعم) \\
\hline Retribution (همi حمح) & $\operatorname{Mercy}($ (تصدح) \\
\hline Judgment (ז.حمح) & Compassion (س山ح) \\
\hline 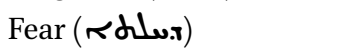 & Encouragement (لهححم) \\
\hline Death ( & Life (ستم) \\
\hline
\end{tabular}


a part of the same revelation. An important point to take into account is the polemical resonances of the opposition amid Goodness and Law to distinguish the revelation in both Testaments. It is not risky to identify in it the echoes of anti-Marcionist polemics. Again, an antecedent can be found in Aphrahat and Ephrem. In his Exposition VII, On penitents, Aphrahat referred to the difference between Goodness and Justice, posing it in an eschatological context:

This world is of Goodness (Rdart) and until it ends there is repentance (rdaح

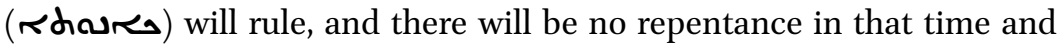
Justice will rest, because Goodness prevails with its force. But when the time of Justice approaches, Goodness will not accept those who repent, because a limit was imposed to it after which there is no repentance. ${ }^{45}$

Aphrahat stated that, as divine qualities, Justice and Goodness coexisted in the present world. But, at the moment of the end, the Goodness (which allowed repentance and forgiveness) will disappear and divine justice will repay men according to their merits. For his part, Ephrem in De Paradiso, XII.12 ${ }^{46}$ alluded to the same distinction as an integral part of God's relation with humankind. He declared: "If there is remission (عمحمك)) we celebrate his Goodness

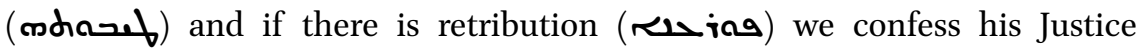
(mdمr)". The polarity Goodness /Justice is fully developed by Ephrem in his polemic against Marcionism. In his Prose refutation against Marcion, ${ }^{47}$ he said that the Marcionists argued against the orthodox Christians by calling their God (Ephrem said مـ مصحم) "our God") "the Just one" i.e. the lesser god of the Old Testament, who made the physical world and may be distinguished from the "stranger" (山iص) God of Marcion's New Testament. This "Just" god - the Marcionists affirmed - permitted the affliction of his

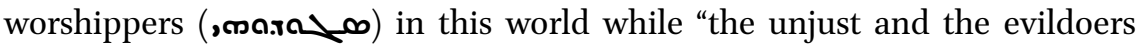
(حقة محבזי, כשrdr) enjoy themselves, and He (God) is found to be good towards evil men". Then Ephrem replied:

The followers of Marcion say concerning each of these things, that is, concerning the justice (arda) of the Just (God) and concerning the Goodness (mdiarb) of their own (God), that it did not come

\footnotetext{
45 Aphraatis sapientis Persae Demostrationes, col. 36o.

46 Des heiligen Ephraem des Syrers Hymnen contra haereses, ed. E. Beck, (csco 169), Leuven, 1957, p. 52.

$47 \quad$ Ephraim's Prose Refutations, p. 54.
} 
and bring relief to the just in this world. But the Goodness of the Maker () i ) is extended even over the followers of Marcion. ${ }^{48}$

Ephrem closed his exposition pointing out the many contradictions in the Marcionists' doctrines about the origin of the physical world and Evil. From his point of view, Goodness and Justice were qualities of the only God, creator of all creation. Justice (as related to the Old Testament) was associated to punishment and retribution while Goodness (of the New Testament) was linked to pardon and remission.

On the basis of this same emphasis on the bond that connected Justice and Goodness, the author of the First Discourse structured the unity of the Scripture. In this way, the mysteries ( fected by the interpretation (حصمعمr) of the New. ${ }^{49}$ Moreover, the continuity between the Old and New testaments derived from the convergence of the same two commandments. Thus, the prophets and the Apostles are part of the dispensation of the same creator:

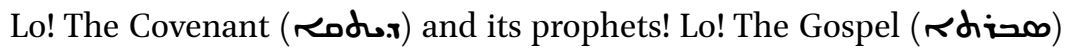
and its Apostles! They are based on the power of two commandments. The former teaches: "Our Lord and Our God is one, and do not hate your brother in your heart so that you will not sin" (Lev. 19.17). And the latter preaches "This is a new commandment: Love each other" (Jn. 13. 34), and believe in God and believe in me ( $C f$.Jn. 14: 119). Both are the soul of each other commandment, one in the other lives and are raised up to life. If one falls the other does not stand. And if one is annulated nothing left form the other. ${ }^{50}$

The Unity of God and the fraternal love constituted the core of the Scripture as a whole, and both the prophets and the apostles were to be considered as part of the same revelation offered by God the creator to mankind. While the Prophets announced the coming of the Saviour, the latter confirmed the truth of their prophecy. As a consequence, sustained the author, it is impossible to deny one without depriving the other of its meaning. To explain this continuity, the author drew on two metaphors: the body and its limbs and the alphabet and the letters:

$48 \quad$ Ephraim's Prose Refutations, p. 55.

49 First Discourse, p. 121.

$50 \quad$ First Discourse, p. 119 . 


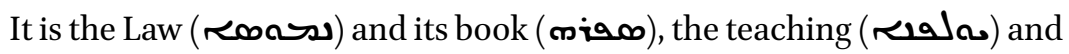
its reading (منسم); they are fixed in the breath of the twenty two signs

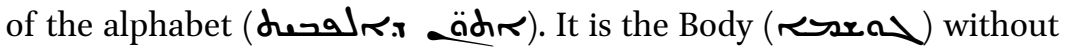
which the limbs do not live, and without them (the Body) cannot sustain itself. In it they speak and they are spoken in it they hear and are heard in it they tell and are told. It is them and they are it. And if it teaches with them, they teach with it, and if they keep silent with it, it keeps silent with them, and if it is instructed with them, they are instructed in it, and if they glorify it, it glorifies them. Through it and through them the construction of the world (حרمיa) became known. And through them and through it, the trinity of the creation (rdoiv rdoodeld) is manifested.51

It is not necessary to point that this metaphor of the body and its limbs the whole and their parts - which resumed the relation of the prophets and Christ has vague resonances to the ecclesiological exegesis of 1 Cor. $12.12-31 .{ }^{52}$ According to the traditional interpretation of that passage, the body (Christ and by extension - the Church) and its limbs were interdependent, to the extent that the whole cannot sustain itself without its parts. In the same way, the knowledge of the Trinity and its intrinsically good creation ${ }^{53}$ was reachable through the revelation which comprised both Testaments. Thus, Christ (the ultimate fulfilling of the revelation) can only be entirely comprehended through the announcements of the prophets (as parts of it). The author reinforced this idea developing the metaphor of the book and the letters written in it:

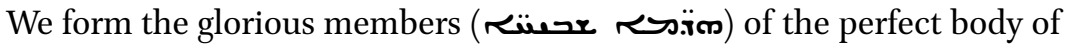

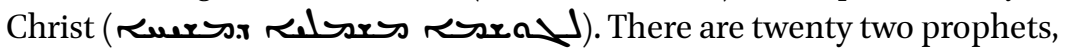
as the book ( $<i a \infty)$ and its letters (mdadir). There would be no letters without the book, the Prophets would be null without the Messiah. There would be no scripture without letters. The Messiah would remain hidden without the prophets. First, we have put Moses, mim is the letter of the Lord (sis), and it is the mystery (iv) of the preaching of God which is in the Prophets. Last, we have written Malachi, mim is the letter

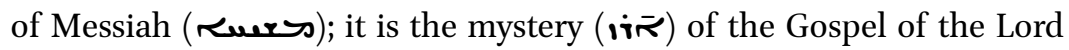

$51 \quad$ First Discourse, p. 120.

$5^{2}$ However, this is not a direct reference to Pauline epistle since the author used the term

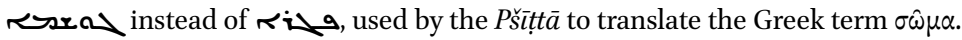


that sealed the Prophets. One revealed us the presence of the lord, and the other manifested to us the person of the Messiah (Rurs as $a_{5}$ ia). ${ }^{54}$

The passage quoted above reminds us of a feature of Jewish and Mandean literatures, that is, the mystical dimension of the alphabet. For Jewish Gnosticism and Mandeans, the Alphabet played an important role in creation. ${ }^{55}$ The author of the First discourse, instead, applied this theory of the alphabet and the letters for a different purpose. On the one hand, the metaphor works in an obvious way. The Scripture and the letters contained in it were an example of the interdependence of the whole and the parts. But the author did not limit himself to this simile. The letters could also contain a certain symbolic (even magical) dimension to the extent that they - as in an acrostic - disclosed their own mysteries. Hence, the author mentioned the letter mim as an example of the hidden symbolism of letters. Mim - explained the author - is the first letter of the names which opened (Moses) and closed (Malachi) the list. Both names enclosed the mystery of the name of the Lord preached by the prophets (the Old Testament) and the one of Christ (the New Testament). Thus, in the very same letter the reader could find the beginning and the end of God's revelation.

The numeric overlap between the letters of the scripture and the names of the prophets fits the First Discourse into a broader tradition about the mystical meaning of the letters. In Jewish and Christian literature the twenty two letters of the alphabet were sometimes associated to a list of twenty two books of the Old Testament. The antecedent of this tradition was Josephus ${ }^{56}$ who counted twenty-two (instead of the twenty four) books in the Bible. However, he did not mention any relation to the letters of the Hebrew alphabet. The first known mention of this feature goes back to the third century. According to Eusebius, Origen related the twenty two Books of the Jewish Scriptures to the twenty two

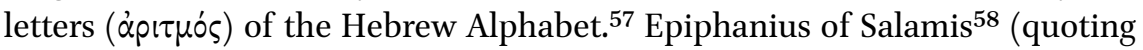
Jubilees 2: 23-24) made a similar observation stating that in the six first days of

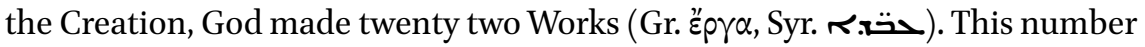

54 First Discourse, pp. 120-121.

55 E. S. Drower, The Secret Adam: A Study of Nasoraean Gnosis, Oxford, 196o, pp. 17-20; D. Cohn-Sherbok, "The Alphabet in Mandaean and Jewish Gnosticism," Religion, 11.3 (1981), pp. 227-234.

56 Contra Apionem, 1.37-43. Flavius Josephus: Against Apion, ed. J. Barclay, Leiden, 200o, 29, see specially note 156 .

$57 \quad H E$ VI.25.3. Cf. PG XII col. 1084.

58 See the Greek text in PG 43 col. 276-280. D. Moutsoulas, "Epiphanius of Salamis' "Concerning Weights and Measures" Introduction, Commentary, Text and Notes," Theologia, 41 (1970), pp. 186-19o, Cf. the Syriac Text in Epiphanius, Treatise on Weights and Measures: the Syriac Version, ed. J. Dean, Chicago, 1935, pp. 100-101. 
coincided with the names of the twenty two "Chiefs" (Gr. $x \varepsilon \varphi \alpha \lambda \alpha$ i, Syr. Rхتі)

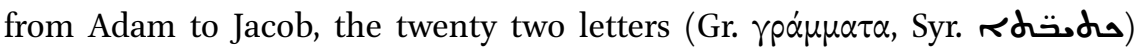
of the Hebrew alphabet and the twenty two books of the Old Testament

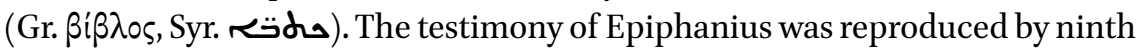
century Nestorian theologian Išō dad of Merv. ${ }^{59}$ Finally, Jerome, in his preface to the Vulgate translation of the Book of Kings, also observed this correlation between the letters of the Hebrew and Syriac alphabets and the number of books in the Jewish Scriptures. ${ }^{60}$

Ephrem took up the same feature in his polemics against Marcionists. He dedicated several of his works (both prose and poems) to the refutation of Mani, Marcion and Bardaisan and, as I previously pointed out, the concepts of Goodness and Justice developed in the First Discourse should be read in conjunction with Ephrem's polemic against Marcion's dualist theology. In fact, his polemic around Goodness and Justice was concomitant with the alphabet's metaphor. In fact, both were instrumental to the polemic against Marcion concerning the Unity of God and Scripture. In the first stanza which introduced the Teachings of Marcion in his Hymn against all Heresies XXII, 1, Ephrem stated:

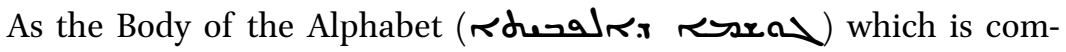

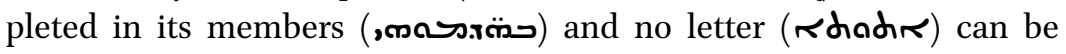
added or removed, so is the Truth that is written in the Holy Gospel with the letters of the alphabet a complete whole that cannot admit either loss or addition. ${ }^{61}$

As Judith Lieu (2015, pp. 167-169) has shown, the unity of God and the harmony of the Scripture were paramount to Ephrem's critique to Marcion's teachings (at least as they were known to him). The metaphor of the completeness of the Truth contained in both Testaments was sustained by the typological relation between the prophets and Christ. Both were bonded by suffering and persecution. From the orthodox point of view, and contrary to the beliefs of the Marcionists, the passion of Christ and the sufferings of apostles and martyrs were not alien to those experienced by the prophets of the Old Testament. In XXXVI, 8 the poet said:

59 Commentaire d'Išǒ dad de Merv sur L'ancien Testament, ed. C. van den Eynde, (csco 156), Leuven, 1955, pp. 3-4.

6o Jérôme, Préfaces aux livres de la Bible, ed. A. Canellis (sc 592), Lyon, 2017, pp. 332-333.

61 Des heiligen Ephraem des Syrers Hymnen contra haereses, p. 169. And the response to the stanza added: "Blessed be your image which is in the alphabet". 


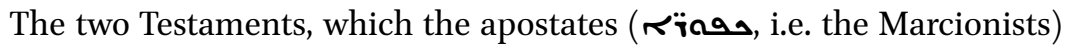
separate, are together one with the other, sealed with harmony. For the Old

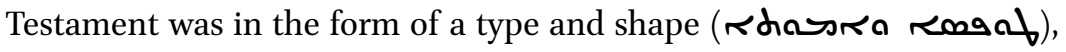
which was modelled for something that remains, and it served and passed away. The New Testament was received inside the types (20ä)) of its companion and was completed. ${ }^{62}$

In the same passage of Prose refutation against Marcion mentioned above, Ephrem related the opposition Justice/Goodness with the unity of the Scripture when discussing the significance of the sufferings of contemporary Christians. Then, he compared them to the Prophets:

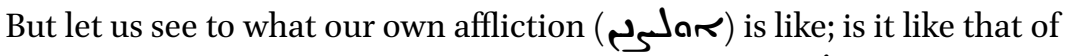

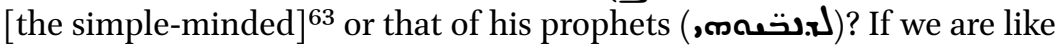
the prophets in our afflictions, how do the followers of Marcion say that (only) in recent times (dord.w) have afflictions been announced? And, again, let us ask the Jews also, that is to say, the Jews and the righteous ones who were among them, whom ought we to resemble? [The others] rather than them we ought to resemble. ${ }^{64}$

To sum up, Ephrem argued that if the Christians resembled the prophets in their afflictions, then it was necessary to sustain the unity of the revelation of the one God creator of the material word. Although First Discourse did not refer to twenty-two books but to twenty two Prophets, we can trace evident similarities with Ephrem's reasoning. In view of these similarities, the question arises: Was this last section of the homily directed against the Marcionists? If it were so, what was the point of this polemic?

It seems apparent that along the fourth and fifth centuries the Marcionist Church was perceived by orthodox writers of the Sasanian Empire as a serious threat. In fact, until the early sixth century, the orthodox were still just one of the many Christian groups. At least, we can consider Marcionism important enough to attract the attention of orthodox writers. In a short passage of Aphrahat's third Exposition, titled On Fasting III.9, the Persian Sage contests the fast practiced by the Marcionists arguing that their theological errors nullify it. ${ }^{65}$ Fifth and sixth century historical sources frequently mentioned them.

62 Des heiligen Ephraem des Syrers Hymnen contra haereses, p. 145.

63 Added by Mitchell.

64 Ephraim's Prose Refutations, pp. 56-57.

65 Aphraatis sapientis Persae Demostrationes, col. 116. 
Jean Maurice Fiey ${ }^{66}$ has compiled an exhaustive catalogue of these sources that, regrettably, provides little information about their ideas and practices. In the History of Simeon Bar Șabba'ē, the Bishop-Martyr admonished his follow-

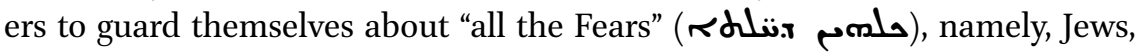
Manicheans and Marcionites. ${ }^{67}$ It is not necessary to accept the historicity of this anecdote, it suffices to stress that - for the author of the biography of the Bishop of Ctesiphon - the interaction with these other three religious communities (he called them rivل rFears") was a sufficiently common practice to forbid it.

To sum up, it is undeniable that orthodox clergy considered Marcionism as a threat. However, the scarcity of details beyond theological asseverations do not allow us to state if the Marcionism of Mesopotamia was a fully organized Church or barely organized circles of initiates mingled within orthodox communities. There are two interesting, although late, testimonies that would shed some light on the characteristics of the Marcionism that combated the author of the First Discourse. The first one comes from the chapter LX of the Chronicle of Seert. We find in it that the celebrated Rabban Abdā of Deīr Qōnī defeated the Marcionists of Bēth Ārāmāyē. The heretics, the author said, have perverted the Christians and spread the magic (سحرا) among them. The saint - the chronicler affirmed without giving details - brought them back to orthodoxy. ${ }^{68}$ Further on, in chapter LIXx, the chronicler described the battle of the Catholic Ahay (410-414), one of the disciples of the aforementioned Abdā, against the Marcionist heresy mingled among the orthodox:

The Catholic commanded to all the fathers to burn every house ${ }^{69}$ in which they found magic science (السحرعلوم) and the instruments of magianism(الات المجوسيّة).BecausetheChristianshavemixedwithMarcionists and Manicheans, and participated of their actions (افتصالهم).70

The XII-XIV century Arab-Christian historians reproduced this information. Although 'Amr ibn Mattā's chapter dedicated to Ahay depended on the Chronicle of Seert, he did not mention Ahay's campaign against the heretics.

66 J. M. Fiey, “Les Marcionites dans les textes historiques de l'église de Perse," Le Museon, 83 (1970), pp. 183-188.

67 The Martyrdom and History of Blessed Simeon Bar Șabba'e, p. 102.

68 Chronique de Séert, p. 308.

69 In this case the meaning of the Arabic word بيت "House" remains unclear. Thus, it is tempting to speculate its exact meaning. Was the author alluding to lay houses, churches or monasteries?

70 Chronique de Séert, p. 325. 
For his part, Șalibā ibn Yūḥānnān his Kitāb al-Mağdal (XIV Century) reproduced the same notice of the Chronicle of Seert but in slightly different terms:

And he (Ahay) ordered the fathers that they deprive (يكروا) every house in which they find something from the magic science of the magi because Marcionists and Manicheans had irrupted and entered among the People. ${ }^{71}$

Although the details contained in these late sources are notoriously inconsistent, the broad picture can contain some historical kernel. In particular, it is worth noting the preoccupation of orthodox clergy for the close contact between Marcionists and Orthodox. This preoccupation was expressed through the accusation of magic or sorcery (السحر equivalent to the Syriac waric) against religious rivals, a common feature of inter-communal polemics in Late Antiquity, in particular in the Iranian culture. ${ }^{72}$ Actually, sorcery was a practice frequently attributed to Marcionists. ${ }^{73}$ In addition, both the Chronicle of Seert and 'Amr ibn Mattā alluded to the interaction between heretics and Orthodox in a liturgical context. In particular, the Chronicle of Seert pointed that the Orthodox Christians interacted with Marcionists and "participated in their actions"; this sentence may indicate that orthodox somehow participated in heretics' celebrations. This affirmation brings the attention back to the feasts dedicated to the martyrs. Sure enough, it is important to bear in mind that this Ahay was the same that we already mentioned as candidate to the authorship of the First Discourse. This coincidence does not mean that Ahay was the actual author of the First Discourse. However, the testimonies of the Arab-Christian chroniclers of the middle ages may reflect older traditions that related Ahay to both the cult of the martyrs and the struggle against Marcionist heresy.

In view of these testimonies, can it be assumed that the cult of the saints was the battlefield in which Orthodox and heretics confronted? There is no clear testimony in East-syriac literature about a Marcionist cult of the Martyrs, but some hints in Latin and Greek literature may point in this direction. Tertullian (I. 14.5; 27.5) signalled the incoherence of the Marcionists that

$71 \quad$ Maris, Amri et Slibae, p. 26.

72 J. Mokhtarian, Rabbis, Sorcerers, Kings, and Priests. The Culture of the Talmud in Ancient Iran, Oakland, 2015; S. Mendoza Forrest, Witches, Whores, and Sorcerers: The Concept of Evil in Early Iran, Houston, 2011.

73 Theodoret ( $H R$ XXI, 15, 11-12) also accused Marcionists of sorcery. See Théodoret of Cyr, Histoire des Moines de Syrie 2, ed. P. Canivet, \& A. Leroy-Molinghen, (sc 257), 1979, p. 94. 
approved martyrdom yet they disregarded the body as a vehicle to sanctity. ${ }^{74}$ In a similar way, Eusebius of Caesarea, quoting the second century writer Apollinaris of Hierapolis, affirmed that the Marcionists "say that they have

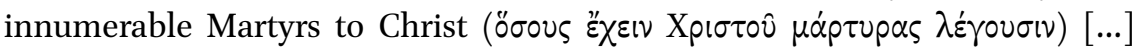
but they do not confess according to truth".75 Although these testimonies do not directly support the existence of a Marcionist cult around the relics of the Martyrs, they imply that, unlike Gnostics, Martyrdom was held in high regard by them. Notwithstanding this, in many respects the devotional practices of the Marcionist Church were similar to those of the orthodox, and the boundaries between both communities may well be blurred. ${ }^{76}$ In other words, it is apparent that the Catena of Testimonia was devised as a polemical tool against theological trends that were identified with Marcionism. Whether it was an organized Church or a diffuse exegetical trend that insisted on the separation between the Old and the New Testament, the author of the First Discourse directed the last section of his Homily against Marcionism. Thus, he appealed to the Scripture in order to prove that persecution and martyrdom were deeply rooted in both Testaments.

\section{4 Conclusion}

In conclusion, the defence of the unity of God and the goodness of his creation, the agreement of both Testaments as parts of the same revelation and the emphasis on the body as a medium to reach God were the basis of the theology of martyrdom in the First Discourse. Those truths were embodied in the Holy Text. Thus, the long Catenae of biblical quotations were designed to sustain a model in which Christ not only was the archetype but also the touchstone that linked past and present. On the other hand, the specific themes and ideas contained in this reveal an underlying debate around the cult of the martyrs. For the author, there was no doubt regarding the prophets' role as models of contemporary martyrs. In this respect, he appealed creatively to a previously established tradition.

74 Quinti Septimi Florentis Tertulliani Opera. Pars I, ed. E. Dekkers, et al., Turnhout, 1954, pp. $45^{6,} 471$.

$75 H E$ V.16, 21. Eusebius: the Ecclesiastical History, ed. K. Lake, Oxford, 1926, p. 482. Cf. the Syriac version: The Ecclesiastical History of Eusebius in Syriac, ed. W. Wright, \& N. McLean, Cambridge, 1898, p. 292. On the other hand, we can mention another testimony that links (by opposition) relics and Marcionism. Theodoret (HR XXI, 15, 18-2O) stated that he was protected from the sorceries of the Marcionists by the relics of the martyrs. Théodoret of Cyr, Histoire des Moines de Syrie 2, p. 94.

76 J. M. Lieu, Marcion and the Making of a Heretic: God and Scripture in the Second Century, Cambridge, 2015, p. 397. 